\title{
A Feasibility Study: Ductless Hydronic Distribution Systems with Fan Coil Delivery
}

D. Springer, B. Dakin, and C. Backman Alliance for Residential Building Innovation (ARBI) 


\begin{abstract}
NOTICE
This report was prepared as an account of work sponsored by an agency of the United States government. Neither the United States government nor any agency thereof, nor any of their employees, subcontractors, or affiliated partners makes any warranty, express or implied, or assumes any legal liability or responsibility for the accuracy, completeness, or usefulness of any information, apparatus, product, or process disclosed, or represents that its use would not infringe privately owned rights. Reference herein to any specific commercial product, process, or service by trade name, trademark, manufacturer, or otherwise does not necessarily constitute or imply its endorsement, recommendation, or favoring by the United States government or any agency thereof. The views and opinions of authors expressed herein do not necessarily state or reflect those of the United States government or any agency thereof.
\end{abstract}

Available electronically at http://www.osti.gov/bridge

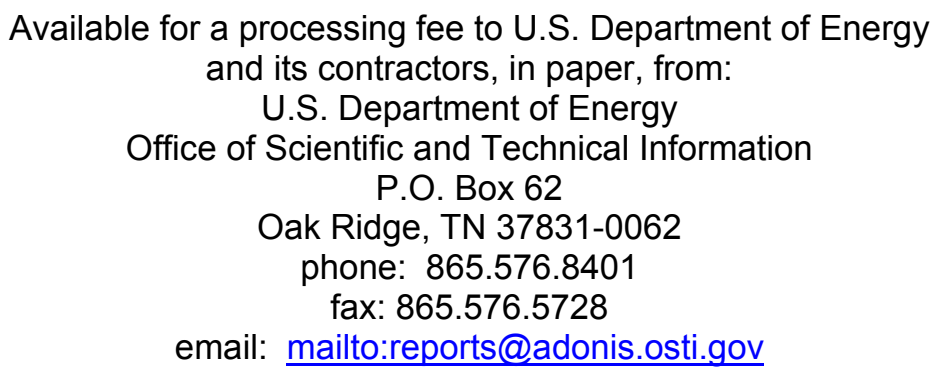

Available for sale to the public, in paper, from:

U.S. Department of Commerce

National Technical Information Service

5285 Port Royal Road

Springfield, VA 22161

phone: 800.553 .6847

fax: 703.605 .6900

email: orders@ntis.fedworld.gov

online ordering: http://www.ntis.gov/ordering.htm

Printed on paper containing at least $50 \%$ wastepaper, including $20 \%$ postconsumer waste 


\title{
A Feasibility Study: Ductless Hydronic Distribution Systems with Fan Coil Delivery
}

\author{
Prepared for: \\ Building America \\ Building Technologies Program \\ Office of Energy Efficiency and Renewable Energy \\ U.S. Department of Energy \\ Prepared by: \\ D. Springer, B. Dakin, C. Backman \\ Alliance for Residential Building Innovation (ARBI) \\ Davis Energy Group, Team Lead \\ 123 C Street \\ Davis, California 95616 \\ NREL Technical Monitor: Cheryn Engebrecht \\ Prepared under Subcontract No. KNDJ-0-40340-00
}

July 2012 
[This page left blank] 


\section{Contents}

Contents

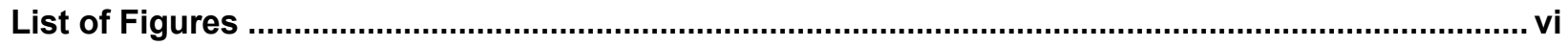

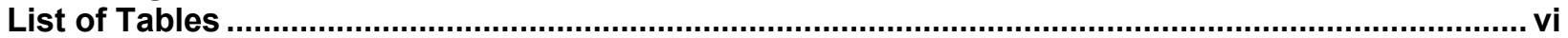

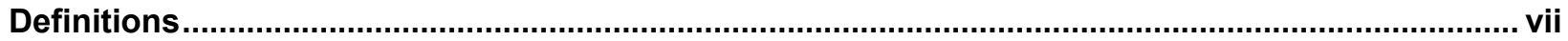

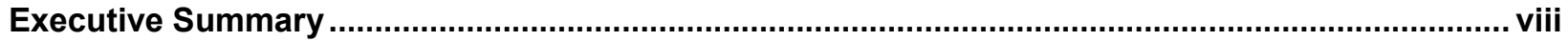

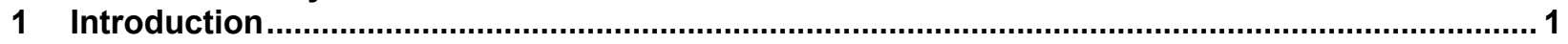

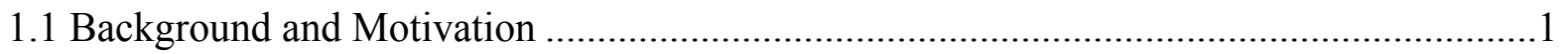

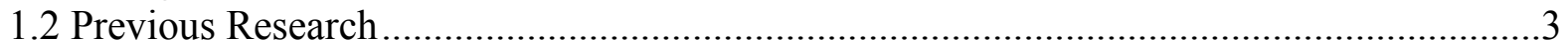

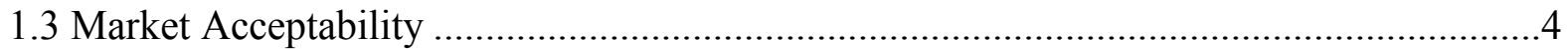

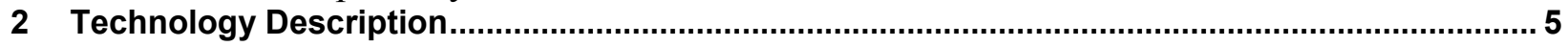

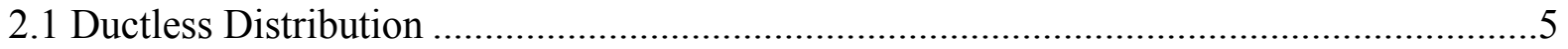

2.2 Hot and Chilled Water Generation ............................................................................ 6

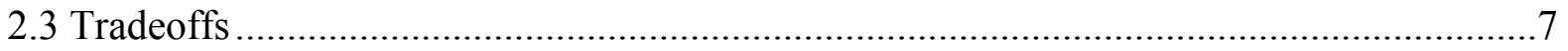

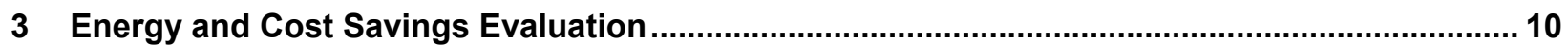

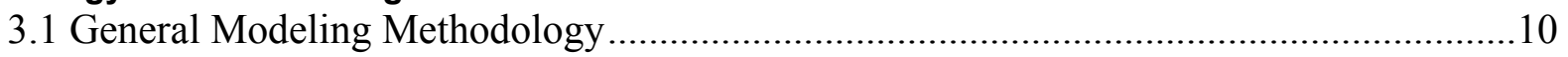

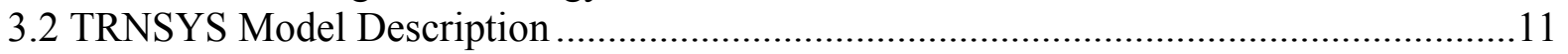

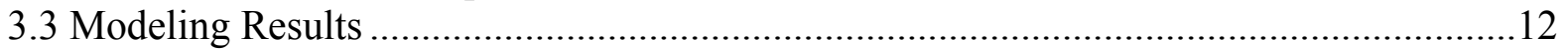

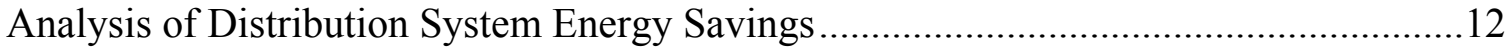

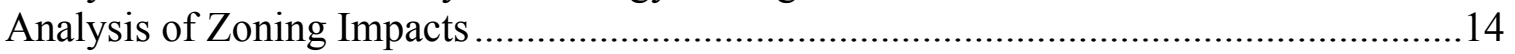

3.4 Cost Estimates and Economic Evaluation ............................................................ 15

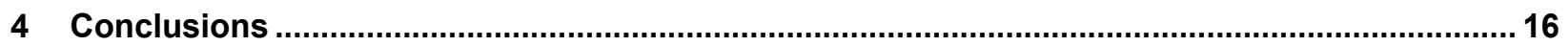

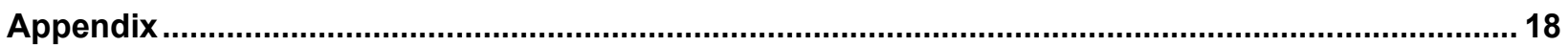

Load Calculations and Equipment Performance Assumptions.......................................... 18

Ductless Hydronic System Assumptions ......................................................................19

Hydronic System Water Flow, Pipe, and Pump Sizing .................................................20

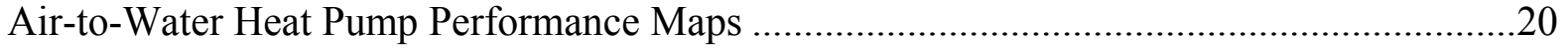

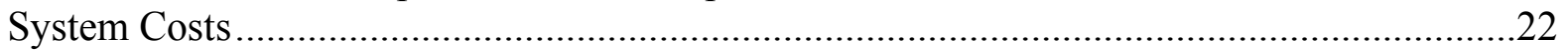

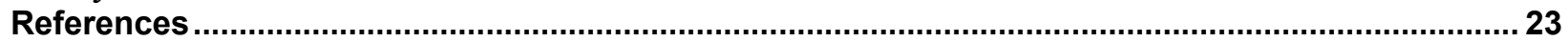




\section{List of Figures}

Figure 1. Non-vented attic houses equipment and ducting ....................................................... 1

Figure 2. Duct chases in conditioned space ............................................................................. 2

Figure 3. Edwards' valance is mounted high on the wall, uses no fans, and can provide heating and cooling.

Figure 4. Airedale's cassette is ceiling mounted and integrates fan, coil, and supply and return

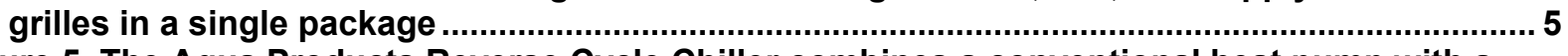

Figure 5. The Aqua Products Reverse Cycle Chiller combines a conventional heat pump with a heat exchanger and control package.

Figure 6. Daikin's Altherma is an inverter-controlled packaged system that can provide water heating in addition to heating and cooling.

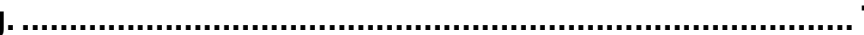

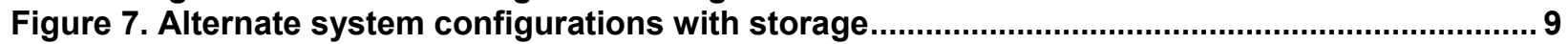

Figure 8. Ducted system floor plan (Base Case) ..................................................................... 10

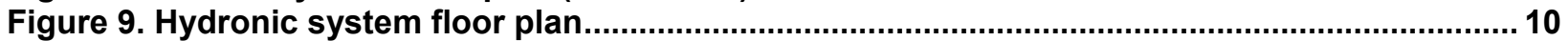

Figure 10. Estimated building loads for ducted and ductless homes .......................................... 11

Figure 11. Indoor temperature profiles during heating for Sacramento house, unzoned case........ 15

Figure 12. Indoor temperature profiles during heating for Sacramento house, multi zoned case .. 15

Unless otherwise noted, all figures were created by the ARBI team.

\section{List of Tables}

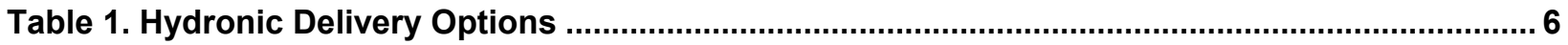

Table 2. Building America House Characteristics for Each Climate Zone...................................... 10

Table 3. TRNSYS Model System Characteristics....................................................................... 11

Table 4. TRNSYS Estimated Annual Site Heating and Cooling Energy Use for Selected Climate

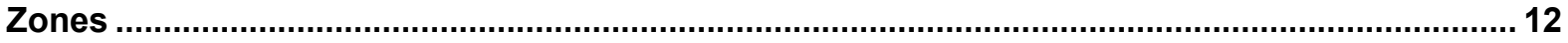

Table 5. Tabulation of Estimated Distribution System Energy Savings .......................................13

Table 6. Energy Use Comparison Between a Single Zone and Multizone Hydronic Distribution for

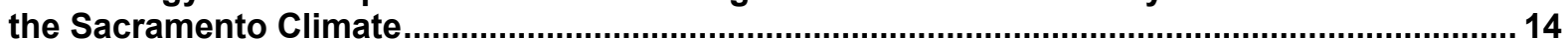

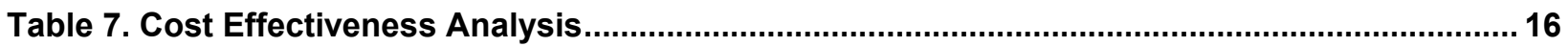

Unless otherwise noted, all tables were created by the ARBI team. 


\section{Definitions}

$\mathrm{AC}$

AFUE

AHRI

ARBI

CFA

DOE-2

EER

EIR

HSPF

HVAC

PEX

RCS

SEED

SEER

WCEC

SHGC

TRNSYS
Air conditioner

Annual fuel utilization efficiency

Air conditioning, Heating, and Refrigeration Institute

Alliance for Residential Building Innovation

Conditioned Floor Area

The DOE-2 building energy simulation program

Energy efficiency ratio

Energy input ratio (used by DOE-2)

Heating seasonal performance factor

Heating, ventilation, and air conditioning

Cross-linked polyethylene

Reverse cycle chiller

Super Energy Efficiency Design

Seasonal energy efficiency ratio

Western Cooling Efficiency Center

Solar Heat Gain Coefficient

Transient System Simulation Tool 


\section{Executive Summary}

Hydronic distribution systems have a long history, and are widely used in commercial buildings. As with mini-split heat pumps, hydronic systems using small terminal fan coils have the potential to provide high-quality comfort to homes that have small heating and cooling loads, but at a lower cost and with greater flexibility. These "ductless hydronic" distribution systems eliminate space requirements needed for ducting, eliminate duct thermal losses, and are easy to zone. Since heat pump chiller-heaters can be charged with refrigerant at the factory, hydronic systems also avoid refrigerant system faults such as incorrect charge and inadequate evacuation of lines that can lead to sub-standard performance. Other advantages include: reduction in the amount of energy required to deliver heating and cooling, reduced equipment cycling, and the potential for incorporating energy storage for peak load avoidance and demand response.

Ductless hydronic systems are best suited for new homes, but with the relative ease of installing piping in attic spaces (for example under attic insulation), they are also suitable for existing homes that have old, leaky, and poorly insulated ducts. With a broader and more affordable product offering from manufacturers, installation guidelines, and contractor training, this method of distribution has significant potential to meet the space conditioning needs of high performance homes.

The primary objectives of this study are to estimate potential energy savings relative to conventional ducted air distribution, and to identify equipment requirements, costs, and barriers. The analysis focuses on ductless hydronic delivery systems that use water-to-air terminal units in each zone. This system type is applicable in all climate regions and can provide sensible and latent cooling and/or heating using a single hot and chilled water source such as a heat pump, or a separate water heater and chiller.

Results of TRNSYS modeling indicate that annual heating and cooling energy use (site and source) can be reduced by up to $22 \%$ when substituting pipes, pump, small distributed fan coils, and a water-to-air heat pump for the ducts, air handler, indoor coil, and conventional air-to-air heat pump unit of similar rating as the air-to-water unit. Of the $22 \%$ savings, on average $36 \%$ is attributable to the lower energy required by pumps and small fans vs. air handler blowers, and $64 \%$ to the reduced losses from pipes as compared to ducts.

Using the modeled energy savings and estimated costs, hydronic distribution appears to be economically viable in three of the four climates evaluated. Other current field studies of air-towater heat pumps coupled to radiant floor systems are demonstrating heat pump performance that exceeds seasonal performance calculated using a standard heat pump performance map (German, 2011a, German, 2011b).

Hydronic distribution systems can meet sensible and latent cooling needs in all climates. Major barriers to widespread application include the lack of low-cost, small, ceiling-mounted fan coils, and the limited availability and higher cost of air-to-water heat pumps. The latter could be overcome by the production of an add-on refrigerant-to-water conversion kit that could be used to adapt any heat pump to serve as a water chiller-heater.

Development of accurate performance maps and additional data on field performance are areas that should be targeted by future research. 


\section{Introduction}

\subsection{Background and Motivation}

The Building America Space Conditioning and Analysis Methods Standing Technical Committee identified the following gaps and barriers that can be addressed by ductless hydronic systems:

- The need for development of low-cost space conditioning strategies for low load homes

- The need to improve thermal efficiency of distribution systems

- The lack of availability of high efficiency, small capacity, cost-effective heating and cooling equipment

"Ductless hydronic" systems, which replace ducts with pipes, use small distributed fan coils that are sized to meet the loads of the zones or rooms in which they are located. Air conditioners, heat pumps, and particularly furnaces used with central forced air systems are often oversized when applied to high performance low-load buildings, resulting in cycling losses for singlespeed air conditioners and heat pumps and poor temperature control (ACCA, 1995). Oversized equipment has also been attributed to poor humidity control in humid climates (Hourahan, 2003).

Hydronic distribution offers several advantages over traditional forced air systems, including reduced surface area of conduits (pipes vs. ducts), elimination of the need for duct chases, substitution of pumps for higher energy use fans, and more efficient zoning (Siegenthaller 2010).

The current strategy to minimize duct losses in new homes is to move ductwork into conditioned space by either creating duct chases within the building enclosure or turning the attic into a nonvented semi-conditioned space.

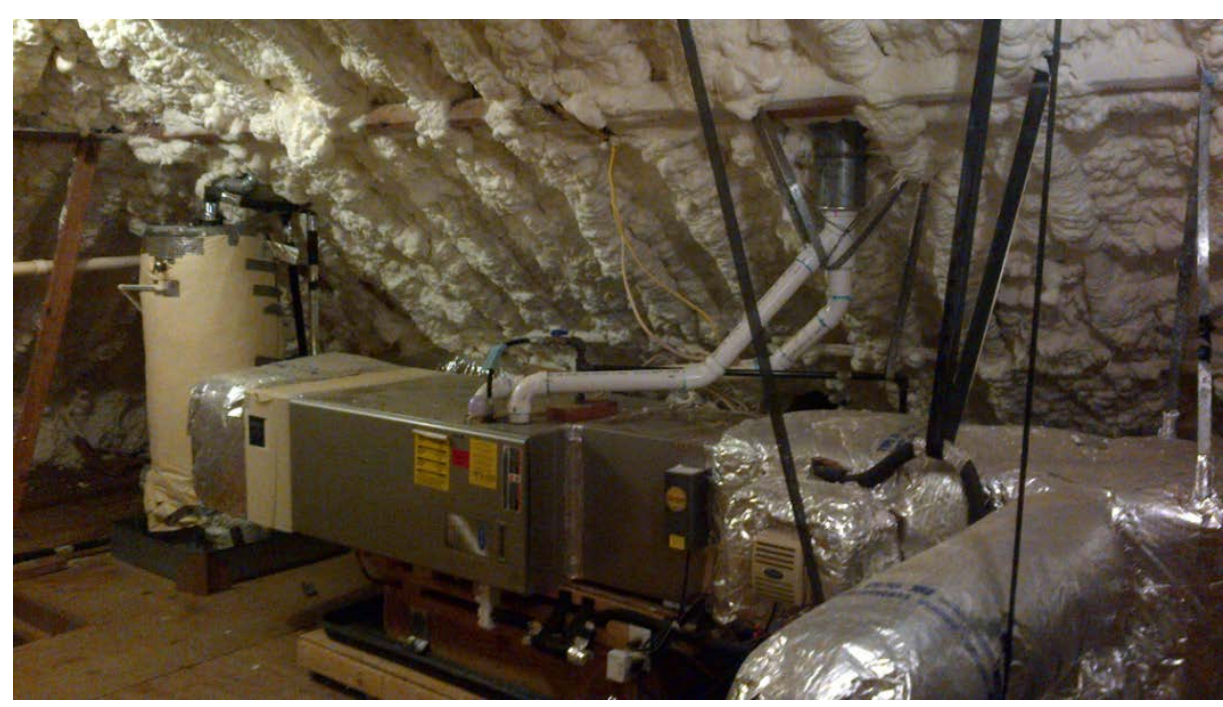

Figure 1. Non-vented attic houses equipment and ducting
Non-vented attics require that insulation is installed at the roof line rather than the attic floor. In addition to being more costly than conventional attic insulation because of the additional material and labor required, this approach increases the surface area of the enclosure, resulting in an increase in building heat transfer, all other things being equal.

Dedicated mechanical chases can present architectural challenges, since duct chases must be aesthetically integrated. Interior equipment consumes floor space and requires creation of 
dedicated mechanical spaces. Creation of duct chases requires specially fabricated trusses and/or lowered ceilings. In order to create the air barrier for the chase, the drywall installer must make two trips, once for the standard wall application and again to drywall around the chase, resulting in added labor and materials costs.

Hydronic distribution eliminates the need to locate ducts in conditioned space. Hydronic piping, which is typically $1 / 2$ " to 1 " in diameter, can easily be routed under attic insulation or through wall cavities within conditioned space.

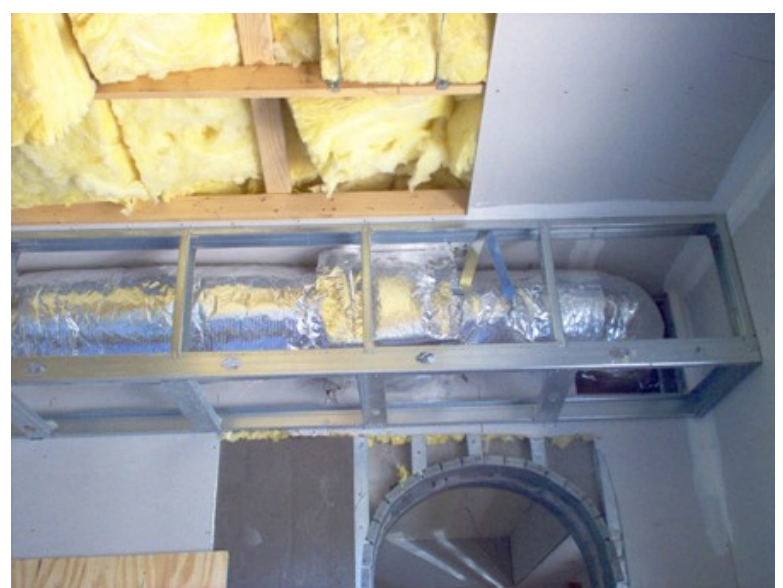

Figure 2. Duct chases in conditioned space

To eliminate the potential for condensation, piping must be insulated with a material that is relatively vapor impermeable, like closed-cell foam pipe insulation, even if it is buried under fiberglass insulation.

Installing multiple hydronic fan coils for cooling does mean that multiple condensate lines must be installed. Condensate drains must to be considered in the design and installation of these systems when they deliver cooling as well as heating.

Hydronic systems can easily incorporate water storage, which can provide demand response capability and can be integrated with solar thermal systems. Unlike conventional single speed gas furnaces, capacity can be varied, allowing greater flexibility for extremely low load high performance buildings. Two other Building America projects underway (ARBI Task Order 2 Projects 2.1 and 3.2) are investigating the potential for improving heat pump effective system EERs and COPs by moderating condenser/evaporator temperatures, which is possible with hydronic systems, particularly when thermal storage is provided.

A method for estimating the efficiency of hydronic distribution systems is included in ASHRAE Standard 152 (Method of Test for Determining the Design and Seasonal Efficiency of Residential Distribution Systems). The standard is currently under review, and significant improvements to the chapter on hydronic distribution have been proposed. Once adopted, the revised standard may prove to be a useful tool for comparing the performance of forced air and hydronic distribution systems under design or seasonal conditions.

In summary, problems that can be mitigated by the application of hydronic distribution include:

- Thermal losses from ducting that is installed in non-conditioned space

- Cost and difficulty of installing ducts in conditioned space

- Restrictions in forced air distribution systems (undersized or restricted ducts) that result in reduced airflow, which particularly affects cooling system performance

- Limited availability of low capacity systems for buildings with low loads 
- Inefficient zoning of forced air systems

- Excessive fan energy use by furnaces and heat pump air handlers

- Distribution limitations and high cost of mini-split heat pumps.

Other factors favoring use of hydronic distribution include:

- The low cost of plastic piping

- The relative ease of installation of piping through framing and under-attic insulation

- The increasing availability of air-to-water heat pumps

- Increasing acceptance of combined hydronic systems and availability of high performance water heating equipment

- The energy storage and demand response capability of hydronic systems

- Avoidance of refrigerant system faults resulting from field installation and charging of refrigerant lines.

Current barriers to hydronic distribution include:

- Contractor unfamiliarity with the technology and implementation strategy

- The division of responsibility between HVAC and plumbing contractors and the additional communication that will be required between these trades.

- The requirements for condensate drains from each terminal unit. Condensate drains are not needed with radiant floor and ceiling distribution provided the chilled water delivery temperature is high enough to prevent condensation on radiant surfaces, or for heating only systems.

- Availability of lower cost air-to-water heat pumps and small capacity fan coils

- Increased potential for leaks and consequent water damage due to the additional use of piping

- Inability of HERS and code compliance software to directly and accurately model hydronic systems.

\subsection{Previous Research}

The first documented installation of a hydronic distribution system was in the Bank of England in 1790. The ASHRAE Systems and Equipment chapters on hydronic distribution and hydronic heating and cooling system design are supported by research that dates as far back as 1920, and design of these systems is well understood (ASHRAE 2008). With the resurgence of interest in radiant systems, a substantial amount of material has been written on radiant heating and cooling distribution in recent years (for example, Siegenthaller, 2011 and Olesen, 2008). Most of the literature is focused on radiant panel and baseboard heating.

Less information is available on non-ducted systems using distributed fan coils. To develop information to aid determination of distribution efficiencies for ASHRAE Standard 152, Vineyard (2000) conducted a field test to measure distribution losses associated with a hydronic system operated in the cooling season. Installed in a 4,300 $\mathrm{ft}^{2}$ two-story home in Newark, New 
Jersey, the system included eight variable speed fan coil units. Vineyard reported measured delivery effectiveness values from $81.4 \%$ to $92.2 \%$ over a range of outdoor temperatures from field tests of systems using distributed fan coils ${ }^{1}$. The distribution efficiency, which included thermal regain from the distribution losses, varied from $87.5 \%$ to $92.5 \%$, meaning that only $12.5 \%$ to $7.5 \%$ of the cooling effect that left the space conditioning equipment failed to reach the conditioned space. Results also showed that the indoor relative humidity was controlled within a range of $46 \%-52 \% \mathrm{RH}$, while the outdoor relative humidity varied from $25 \% \mathrm{RH}$ to $100 \% \mathrm{RH}$.

Putting the results from the single field test by Vineyard in perspective, measurements of five ducted systems in California homes by Siegel (2002) found delivery effectiveness values ranging from $76 \%$ to $91 \%$ and averaging $85 \%{ }^{2}$. In these houses, which ranged from 1010 to $1670 \mathrm{ft}^{2}$, the ducts were well insulated and measured leakage to outside averaged $6 \%$ of measured air handler flow.

Ongoing Building America research on two homes with radiant heating and cooling is shedding additional light on distribution efficiency for radiant floor systems. At one of the sites, the temperature difference across under-slab insulation and the thermal resistance of the insulation were used to calculate an average distribution efficiency of $98.3 \%$ over one cooling season (German, 2011a). Both the underside and edge of the slab was insulated to R-10. Applying ASHRAE Standard 152 calculation methods, the same house with a typical forced-air system with ducts located in the attic would have a seasonal distribution efficiency of $65 \%$ with $15 \%$ leakage and $78 \%$ with $6 \%$ leakage.

\subsection{Market Acceptability}

Hydronic distribution is not a new concept, but residential systems that provide both heating and cooling delivery are rare. Heating-only hydronic distribution systems using baseboard convectors are common in New England states and radiant heating is being more widely applied in custom homes due to the low cost and durability of PEX tubing and the reputation for comfort that radiant heating has earned. Other systems that use hydronic distribution to some degree include commercial "four-pipe" hot/chilled water systems and combined hydronic systems, which are commonly used in multifamily buildings. The perception that cooling cannot be provided by hydronic systems, as well as HVAC contractor inexperience with "wet" systems (particularly in the western United States), contribute to the slow adoption of this technology. Field testing and energy modeling of systems will improve knowledge of the energy savings potential and commercial viability of these systems, and will help to identify the necessary subsequent steps needed for commercialization.

\footnotetext{
${ }^{1}$ ASHRAE 152P defines delivery effectiveness as the ratio of thermal energy transferred to or from the conditioned space to the thermal energy transferred at the equipment/distribution system heat exchanger. Delivery effectiveness fails to fully represent the fraction of the supplied energy that reaches the conditioned space to satisfy the building load. Distribution efficiency is defined as the ratio between the energy consumption by the equipment if the distribution system had no losses and the energy consumed by the same equipment connected to the distribution system, and takes into account effects of thermal regain, and the impact, if any, of the distribution system on the equipment efficiency.

${ }^{2}$ Siegel did not report distribution efficiency. Delivery effectiveness varies from distribution efficiency primarily by the regain factor, which is close to unity.
} 


\section{Technology Description}

\subsection{Ductless Distribution}

Hydronic systems distribute heating and cooling using piping to convey hot or chilled water to either convective devices or radiant panels. Radiant systems employ traditional radiators, radiant floor slabs, or radiant wall and ceiling panels to deliver comfort using predominantly radiant heat transfer. Convective systems include small, distributed fan coils, baseboard convectors, or valance systems. Fan coils (or air handlers) are commonly used with ducting, but can also be used to deliver air directly to spaces or through very short ducts that can be distributed within each zone and kept within the conditioned enclosure. Baseboard convectors and valance systems rely on natural convection (no fans). Baseboards can only be used for heating but valance units (shown in Figure 3) include condensate drains and can deliver both heating and cooling.

Self-contained ceiling-mounted fan coils similar to the Airedale brand shown in Figure 4 integrate the fan, coil, and supply/return grilles in a single ceiling-mounted unit. These units are similar to the cassettes used with mini-split heat pumps except that water, rather than refrigerant, is circulated as the heat transfer fluid. Airedale's ceiling mounted cassette has a fan efficacy of $0.16 \mathrm{~W} / \mathrm{cfm}$ compared to the typical $0.58 \mathrm{~W} / \mathrm{cfm}$ of furnaces, which can result in significant fan energy savings, especially if the cassettes are separately zoned. However, the market for these systems is still primarily commercial buildings.

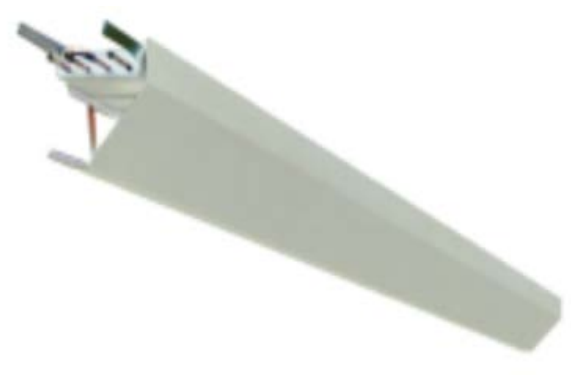

Figure 3. Edwards' valance is mounted high on the wall, uses no fans, and can provide heating and cooling

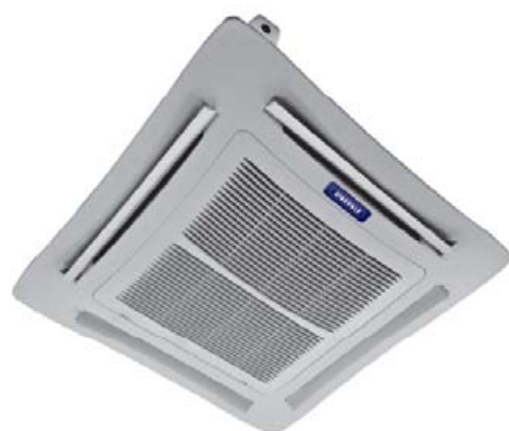

Figure 4. Airedale's cassette is ceiling mounted and integrates fan, coil, and supply and return grilles in a single package

Several manufacturers, such as Williams Comfort Products, First Company, and MagicAire offer small hot/chilled water fan coil products that can be installed in ceiling spaces or closets with little or no ducting. These are commonly seen in high-rise hotels.

Radiant heating systems are frequently used in custom homes and typically use PEX tubing, either embedded in the floor slab, or installed under, within, or over the subfloor. Radiant floor cooling is much more limited due to limited available cooling capacity and risk of condensation on the floor surface. If the floor surface temperature drops below the indoor dewpoint temperature, moisture from the air will condense and collect on the surface. Because of the potential for moisture damage from condensation, radiant floor cooling must only be used with exposed concrete slabs or slabs with ceramic tile or stone coverings. Carpeting and wood floors 
increase the risk of floor condensation as well as provide a better medium for mold growth, and vinyl flooring acts as a vapor barrier to trap the condensed moisture. Field tests conducted in dry climates have shown that it is possible to meet design cooling loads while keeping the floor surface temperature comfortably above the dewpoint temperature of indoor air (German, 2011a and Springer, 2007).

Cooling can also be accomplished with some radiant ceiling products. For example, BEKA, a German manufacturer, offers mats made of micro-tubes that can be installed in plaster ceilings. Radiant ceiling panels provide certain benefits over radiant floor systems including increased capacity $^{3}$, reduced risk of condensation (if installed properly) ${ }^{4}$, and elimination of restrictions on floor coverings, but they are more costly to install than slab-on-grade systems. Table 1 summarizes available hydronic distribution delivery options.

Table 1. Hydronic Delivery Options

\begin{tabular}{|l|l|l|}
\hline Delivery Options & Load type & Forced Air \\
\hline "Pancake" fan coil or ceiling cassette & Heating or Cooling & Yes \\
\hline Baseboard Convector & Heating Only & No \\
\hline Wall radiators & Heating Only & No \\
\hline Ceiling Panels & Heating or Cooling & No \\
\hline Slab-on-Grade Radiant Floor & Heating or Cooling & No \\
\hline Raised Floor Radiant Applications & Heating Only & No \\
\hline Valence Convector & Heating or Cooling & No \\
\hline
\end{tabular}

\subsection{Hot and Chilled Water Generation}

Hot water can be easily sourced from water heaters or boilers. For radiant heating systems, it is typical to isolate the water in the distribution tubing from potable water using a heat exchanger due to concerns about contamination of water standing in tubes over long periods of time. For fan coils, potable water is commonly circulated directly through the heating coil using stainless steel or bronze fitted pumps. Ferrous components such as cast iron pumps and steel panel radiators must also be isolated to avoid corrosion resulting from oxygen that is present in open systems. Hot water can also be generated using water source heat pumps such as ground-coupled heat pumps, or air source (air-to-water) heat pumps. Electric resistance heaters are not generally used because of the high operating cost and large electrical demand.

Air-to-water heat pumps operate on the same mechanical principals as air-to-air split system heat pumps that have been on the market for several decades, and with proper installation and commissioning procedures, they can provide the same durable and reliable operation. Automatic defrost cycles allow the units to be operated at very low ambient temperatures, often below $0^{\circ} \mathrm{F}$.

\footnotetext{
${ }^{3}$ Radiant ceiling panels have a higher heat transfer coefficient in cooling mode than radiant floors (1.63 versus 1.08 $\mathrm{Btu} / \mathrm{hr}-\mathrm{ft} 2-\mathrm{F}$ ) (ASHRAE, 2008).

${ }^{4}$ Because of higher cooling heat transfer coefficient and resultant cooling capacity per square foot of ceiling area, higher chilled water supply temperatures can be delivered through ceiling panels, reducing the risk of condensation.

${ }^{5}$ Appropriate only in dry climates with exposed concrete or tile floors to prevent condensation moisture issues.
} 
Ground coupled water-to-water heat pumps that produce hot and chilled water have been available for many years. However, the high cost of installing the ground heat exchangers limits their market acceptability in many areas of the United States.

While large commercial chillers are widespread, there are few on the market that are sized for residential or small commercial loads. Currently, there are only three heat pump products on the U.S. market that produce hot and chilled water. The Aqua Products "Reverse Cycle Chiller" (RCS) pairs a conventional heat pump with a refrigerant-to-water heat exchanger to generate hot and chilled water (see Figure 5). Multiaqua produces a variety of chillers and chiller-heaters for the residential and commercial sectors. The Daikin Altherma (Figure 6) is a newcomer to the U.S. market and makes domestic hot water in addition to hot and chilled water for heating and cooling. Unico, known for their high velocity duct systems, produces a "UniChiller" selfcontained air-to-water heat pump. LG makes a product similar to the Altherma, but they have not yet released it to the U.S. market. These systems produce water that is in the range between $40^{\circ} \mathrm{F}$ and $125^{\circ} \mathrm{F}$.

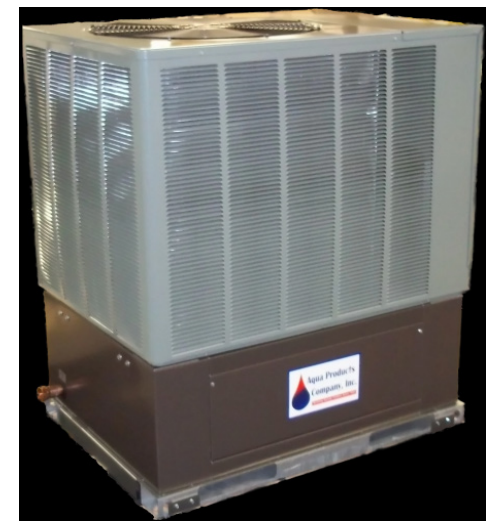

Figure 5. The Aqua Products Reverse Cycle Chiller combines a conventional heat pump with a heat exchanger and control package.

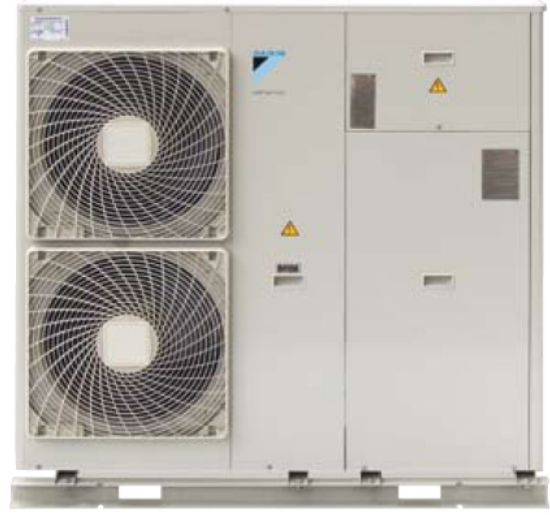

Figure 6. Daikin's Altherma is an invertercontrolled packaged system that can provide water heating in addition to heating and cooling.

Carrier produced a coaxial heat exchanger (09WQ) in the 1980s that could be used to convert their heat pumps into water chiller-heaters. Others have used brazed plate heat exchangers to convert condensing units to water chillers (Smith, 2003 and Springer, 2007). The conversion can be accomplished by any reasonably skilled HVAC practitioner.

Local codes can prove to be an obstacle to manufacturers of residential chillers and air-to-water heat pumps because there is no U.S. standard for rating their performance. Daikin found it necessary to appeal to the California Energy Commission to obtain a heating performance rating better than the minimum DOE standard value of 7.7 HSPF. Based on European test results they were granted an HSPF of 11.0. (CEC 2012).

\subsection{Tradeoffs}

Significant energy savings stemming from the replacement of hydronic heating and cooling distribution systems are expected, mostly resulting from tradeoffs between fan and pump energy use and between duct losses and pipe losses. Additional savings may also derive from zoning and improved part load performance, depending on the design and application. 
Heating and Cooling Plant Options. Integrated systems with inverter driven heat pumps like Daikin's Altherma tend to be much more expensive than built-up systems that use conventional heat pumps and add on controls and components, like the Aqua Products RCS. Preliminary data suggests Altherma heating performance is much higher than for standard heat pumps; however, rated cooling performance is not exceptional. Their best application may be for all-electric houses because of their ability to efficiently heat domestic hot water. Their variable speed capability also favors systems that have zoning and use fan coils instead of radiant slabs for distribution. Where low cost is a high priority, built-up systems similar to Aqua Products' RCS will be a better choice, and they can be ordered with heat pumps of various efficiencies.

Distribution System Tradeoffs. A radiant distribution system can be installed for under $\$ 1.30$ per $\mathrm{ft}^{2}$ (RS Means 2011, assuming 75\% coverage). Addition of insulation below the slab and at the edges adds to the cost, but also improves year-round performance of the building. In climates requiring cooling, radiant floor distribution cannot be used with vinyl, carpet, cork, wood, or other non-ceramic floor coverings due to risk of floor condensation and damage to flooring materials, though limited use of carpeting and throw rugs may be acceptable. Slab-on-grade radiant floor systems provide optimal comfort, and because their high mass allows them to store energy and shift loads, they can reduce operating costs where utility time-of-use rates are in place. Preliminary research results also show that the floor heating and cooling used in buildings with tight enclosures allows systems to be operated at times that produce higher heat pump performance (German, 2011b). For example, heating can be operated during the daytime when outdoor temperatures are higher, and cooling during the nighttime when outdoor temperatures are lower.

Houses on raised floor foundations and wood-framed floors of multistory buildings are best served by forced air delivery using fan coils with no or very short ducts serving individual spaces when cooling is required. Fan coil options include cassettes (as in Figure 4), or small conventional ceiling or closet-mounted fan coils. Small hydronic cassettes have efficiency and space advantages but are not manufactured or commonly used in the United States, and tend to cost more than conventional fan coils. An opportunity exists for the manufacture of low capacity, low cost ceiling mounted fan coils that are designed specifically for the residential market. Fan coil motor energy use should be considered when selecting equipment for forced air systems. Fan motor energy use can far exceed pump energy use, but fan coils that use efficient brushless permanent magnet motors are available and will improve the overall efficiency of the system.

The use of baseboard and valence systems may be limited by their lower aesthetic appeal. Baseboard heaters are designed for heating only and are typically designed to be used with supply water temperatures over $140^{\circ} \mathrm{F}$.

System Design Tradeoffs. Inverter-driven heat pumps (or variable capacity water heaters in heating only systems) may be installed without storage because they can vary capacity and are less likely to short cycle when loads are low during mild conditions or when not all zones are calling for heating or cooling. When slab-on-grade radiant floor distribution is used, single speed heat pumps and chillers may be installed without water storage, provided that the smallest zone is able to absorb sufficient energy to keep the heat pump from short-cycling. Otherwise, radiant and convective systems should include sufficient storage volume to allow the system to operate for at least 5 minutes under low load conditions. Storage tanks may either be installed in parallel 
or in series as shown in Figure 7. The parallel configuration may require larger storage capacity but is preferred when used with fan coils because of the faster response time. However, storage losses will be greater with this configuration because the tank must be always maintained at the required heating or cooling temperature. The series configuration only requires a single pump and simplifies controls ${ }^{6}$.
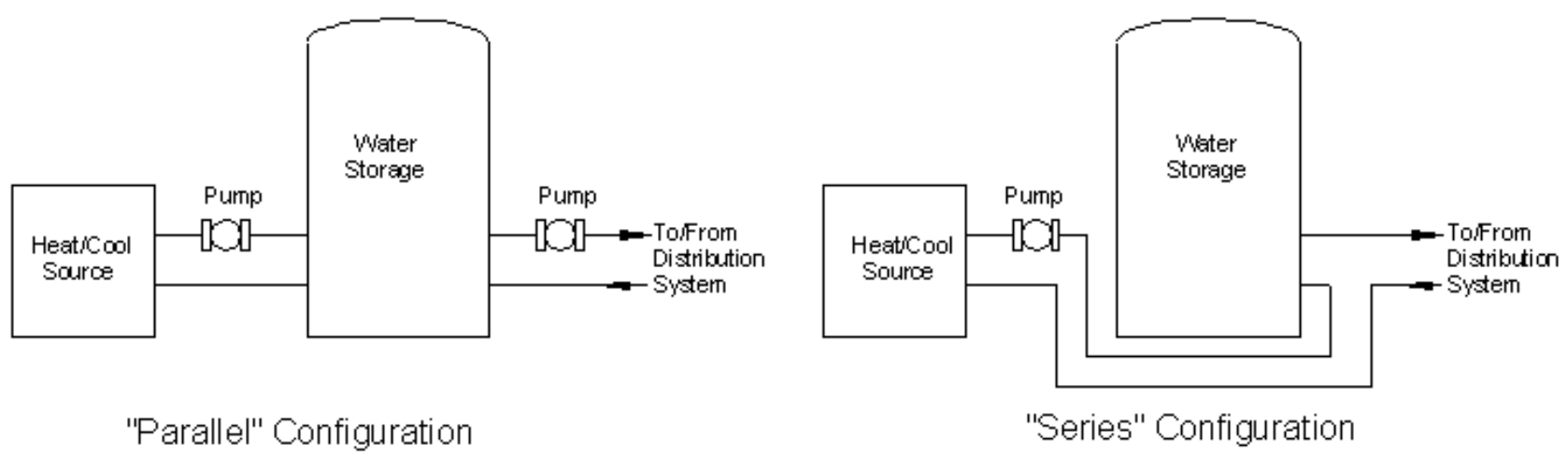

Figure 7. Alternate system configurations with storage

\footnotetext{
${ }^{6}$ This information is general and there are many other considerations. References such as Siegenthaller (2010) should be consulted for detailed information on design requirements of hydronic systems.
} 


\section{Energy and Cost Savings Evaluation}

\subsection{General Modeling Methodology}

To estimate performance and potential energy savings, TRNSYS Version 17 was used to model a typical house with a ducted system (Figure 8 ) and alternatively with a hydronic distribution system (Figure 9). A model of a 2,400 $\mathrm{ft}^{2}$ single story, slab-on-grade house was developed using characteristics of the Building America Benchmark home. Window area is approximately equal in all orientations. Heating and cooling set points of $72^{\circ} \mathrm{F}$ and $76^{\circ} \mathrm{F}$ were used, respectively. Various simulation time steps were investigated and a 5-minute time step was ultimately used providing a compromise between simulation time and accuracy.

The house was simulated in four cities representing three climate regions: Hot-Dry, Hot-Humid, and Cold. The standard 2010 Building America simulation protocol assumptions were applied as listed in Table 2, corresponding to the climate zones modeled (DOE, 2010).

Table 2. Building America House Characteristics for Each Climate Zone

\begin{tabular}{|l|l|l|l|l|}
\hline Climate Region & Hot-Dry & Hot-Humid & Cold & Hot-Dry \\
\hline City & Sacramento, CA & Houston, TX & Denver, CO & Phoenix, AZ \\
\hline Wall Type & R-13 & R-13 & R-13+5 & R-13 \\
\hline Window U-Value/SHGC & $0.40 / 0.30$ & $0.40 / 0.30$ & $0.35 / 0.35$ & $0.40 / 0.30$ \\
\hline Ceiling Insulation & 30 & 30 & 38 & 30 \\
\hline Slab Insulation/depth & 0 & 0 & R-10 for $2 \mathrm{ft}$ & 0 \\
\hline
\end{tabular}

Figure 8 and Figure 9 show the heat pump system duct layout for the conventional design and the piping and fan coil layout for the hydronic distribution design, respectively. Sizing of heat pumps, ducts, and pipes was completed using ACCA manual J and D.

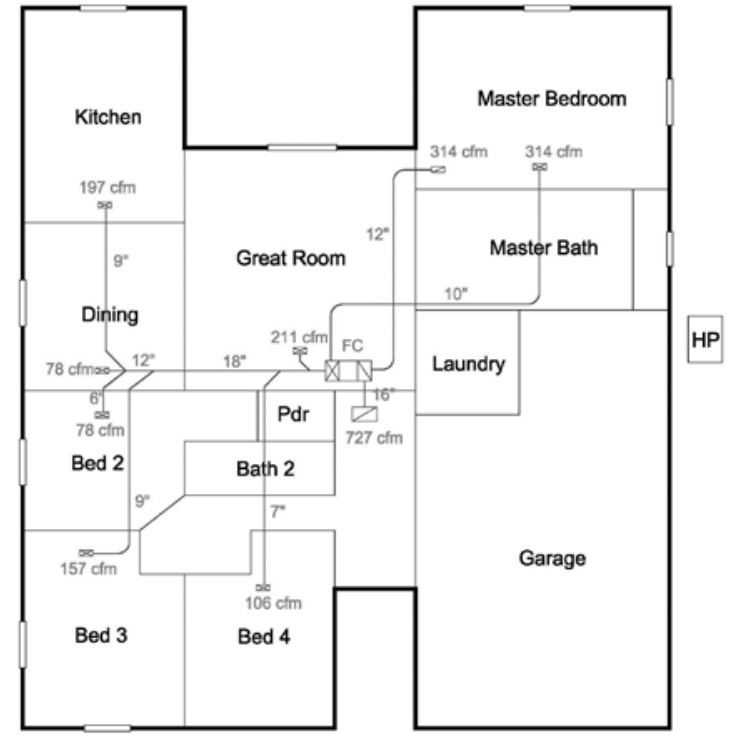

Figure 8. Ducted system floor plan (Base Case)

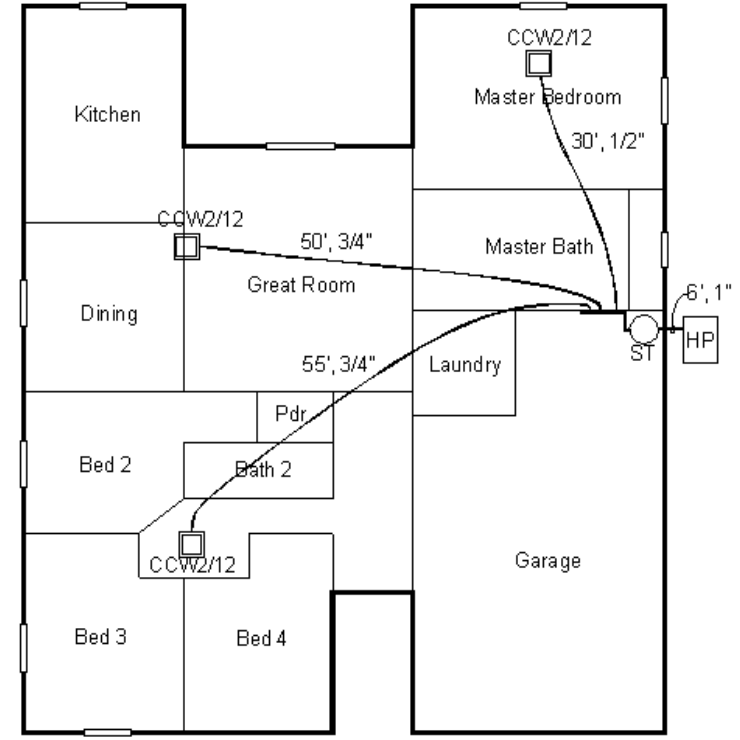

Figure 9. Hydronic system floor plan

\footnotetext{
${ }^{7} \mathrm{R}-13+5$ means R-13 cavity insulation with R-5 continuous insulating sheathing on the exterior
} 
Figure 10 shows the calculated heating and cooling design loads for each case. The elimination of attic ducts resulted in an average reduction of heating loads of $23 \%$ and reduced cooling loads on average by $35 \%$. Additional sizing information is provided in the Appendix.

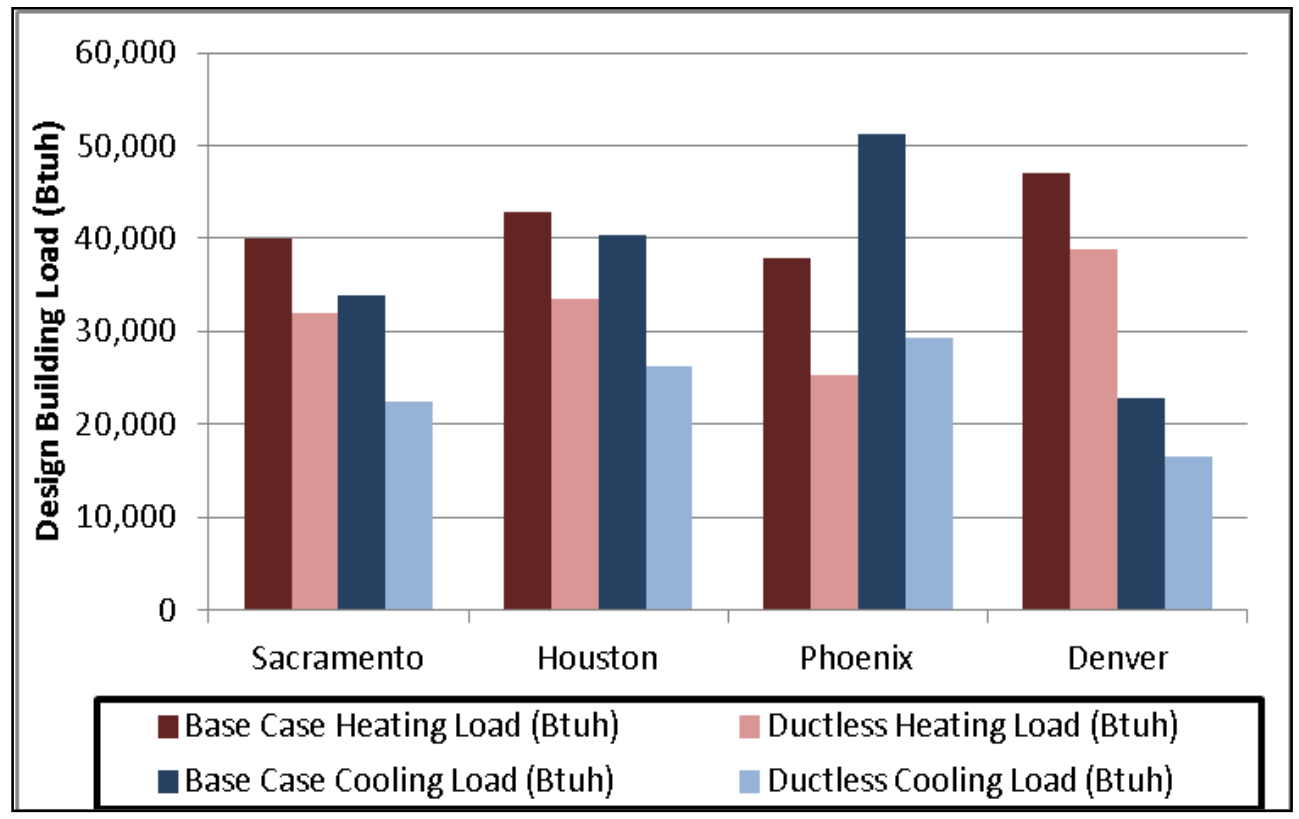

Figure 10. Estimated building loads for ducted and ductless homes

\subsection{TRNSYS Model Description}

The base case TRNSYS model incorporated a ducted air-to-air heat pump rated at 13 SEER and 7.7 HSPF (11 EER cooling and 3.28 COP heating at rated conditions). The model assumed a centrally located air handler with a DX heating and cooling coil and a single zone thermostat located in the Great Room. Ducts, located in the vented attic, were assumed to have R-8 insulation and a leakage rate of $15 \%$ of cooling airflow (see Table 3 ).

Table 3. TRNSYS Model System Characteristics

\begin{tabular}{|l|l|l|}
\hline & Base Case & Hydronic \\
\hline System Description & $\begin{array}{l}\text { Central ducted split-system } \\
\text { air-source heat pump with air } \\
\text { handler in attic }\end{array}$ & $\begin{array}{l}\text { Air-source heat pump outdoor } \\
\text { unit connected to refrigerant- } \\
\text { to-water heat exchanger }\end{array}$ \\
\hline Distribution System & $\begin{array}{l}\text { R-8 ducts located in vented } \\
\text { attic. Duct leakage }=15 \% \text { of } \\
\text { rated air flow }\end{array}$ & $\begin{array}{l}\text { Hydronic distribution to small } \\
\text { fan coils. Minimal ducting in } \\
\text { conditioned space. }\end{array}$ \\
\hline Heat Pump Efficiency & $11 \mathrm{EER} / 3.28 \mathrm{COP}$ & $11 \mathrm{EER} / 3.28 \mathrm{COP}$ \\
\hline Fan Airflow & $0.028 \mathrm{cfm} / \mathrm{Btuh}$ & $0.024 \mathrm{cfm} / \mathrm{Btuh}$ \\
\hline Fan Power W/cfm & $0.365 \mathrm{~W} / \mathrm{cfm}$ & $0.365 \mathrm{~W} / \mathrm{cfm}$. \\
\hline
\end{tabular}

The TRNSYS model for the air-to-air heat pump used the DOE-2 coefficient approach for heat pump performance, which determines off-rated power and capacity using a bi-quadratic equation. Base case heat pump coefficients were taken from the option editor in BEopt v1.1, 
which also provided the parameters for fan flow $(0.028 \mathrm{cfm} / \mathrm{Btuh})$ and fan power $(0.365 \mathrm{~W} / \mathrm{cfm})$. For the ductless hydronic case, an air-to-water heat pump having the same rated efficiency values as the air-to-air heat pump was applied in the model. However, the TRNSYS model for an air-to-water heat pump requires use of a performance map for off-rated conditions in a unique format distinct from the DOE-2 coefficient approach, for which the only available data is that based on manufacturer specifications. Given that the only performance data available for air-towater heat pumps at the time was for the inverter driven Daikin Altherma, this data was used to develop the air-to-water heat pump performance map. Further details regarding the performance parameters are provided in the Appendix.

Performance characteristics of the fan coils were based on three MagicAire fan coils serving the living/kitchen area, master bedroom, and guest bedrooms. Each fan coil was scheduled to deliver between 200 to $500 \mathrm{cfm}$, depending on zone loads, at $0.365 \mathrm{~W} / \mathrm{cfm}$. See the Appendix for background on these assumptions. All terminal units were operated from a single thermostat located in the living room. Additional simulations were completed to investigate the impact of having each fan coil controlled by a thermostat located in the respective zone.

\subsection{Modeling Results}

\section{Analysis of Distribution System Energy Savings}

Table 4 lists TRNSYS predictions of energy use by end-use for the two cases for four climate regions. The substantial energy savings (averaging 55\%) are due to both improved distribution efficiency of the ductless hydronic case, and to a large extent, improved part load efficiency of the heat pump. Savings in heating mode were slightly higher than for cooling.

Table 4. TRNSYS Estimated Annual Site Heating and Cooling Energy Use for Selected Climate Zones

\begin{tabular}{|l|c|c|c|c|c|c|c|c|}
\hline \multirow{2}{*}{$\begin{array}{l}\text { Energy Use } \\
\text { (kWh/yr) }\end{array}$} & \multicolumn{2}{|c|}{ Sacramento } & \multicolumn{2}{c|}{ Houston } & \multicolumn{2}{c|}{ Phoenix } & \multicolumn{2}{c|}{ Denver } \\
\cline { 2 - 9 } & $\begin{array}{c}\text { Base } \\
\text { Case }\end{array}$ & $\begin{array}{c}\text { Ductless } \\
\text { Hydronic }\end{array}$ & $\begin{array}{c}\text { Base } \\
\text { Case }\end{array}$ & $\begin{array}{c}\text { Ductless } \\
\text { Hydronic }\end{array}$ & $\begin{array}{c}\text { Base } \\
\text { Case }\end{array}$ & $\begin{array}{c}\text { Ductless } \\
\text { Hydronic }\end{array}$ & $\begin{array}{c}\text { Base } \\
\text { Case }\end{array}$ & $\begin{array}{c}\text { Ductless } \\
\text { Hydronic }\end{array}$ \\
\hline $\begin{array}{l}\text { Heat Pump } \\
\text { Heating }\end{array}$ & 7,825 & 3,241 & 3,965 & 1,789 & 3,095 & 1,254 & 13,098 & 6,089 \\
\hline $\begin{array}{l}\text { Heat Pump } \\
\text { Cooling }\end{array}$ & 1,104 & 522 & 3,808 & 1,877 & 7,450 & 3,102 & 512 & 276 \\
\hline Fan and Pump & 1,470 & 609 & 1,367 & 769 & 2,625 & 973 & 1,260 & 746 \\
\hline Total & 10,398 & 4,373 & 9,140 & 4,435 & 13,171 & 5,329 & 14,870 & 7,112 \\
\hline
\end{tabular}

As previously described, the air-to-water heat pump was modeled using part load curves from the Altherma, which modulates capacity based on load, and the air-to-air heat pump used the generic DOE-2 heat pump curves. Even though the air-to-water heat pump performance was calibrated to provide similar heating and cooling EIRs as the air-to-air heat pump at rated conditions, the off-rated part load performance of the air-to-water system produced unexpectedly high energy savings, which were a substantial contributor to total savings.

For the purposes of this study, the critical outcome is the reduction in distribution system energy use, which includes duct or piping losses and fan and pump energy use, but not necessarily differences in heat pump performance. Since the heat pump models used in the conventional and 
hydronic systems were based on different sources of information and different performance curves, the modeling results may include biases that decrease the significance of the predicted heat pump energy savings. In order to separately identify distribution savings, the seasonal efficiencies (effective COP and EER) of the standard heat pump system were calculated by dividing annual delivered heating and cooling energy by the annual heating and cooling electric use (excluding indoor fan) that were computed by TRNSYS for the base case. These efficiencies were then multiplied by the delivered energy for the ductless hydronic case from TRNSYS to develop the estimated outdoor unit electric use for the hydronic system. Finally, fan and pump energy were added to the seasonal energy use to obtain total annual energy use for each distribution system type to obtain the results presented in Table 5. Annual site electric savings range from a low of $16 \%$ for Houston to a high of $27 \%$ for Sacramento and Denver. On average, $36 \%$ of the savings is attributable to the lower energy required by pumps and small fans vs. heat pump air handler blowers, and 64\% to the reduced load imposed by pipe vs. duct losses.

Table 5. Tabulation of Estimated Distribution System Energy Savings

\begin{tabular}{|c|c|c|c|c|c|c|c|c|c|}
\hline & \multicolumn{2}{|c|}{$\begin{array}{c}\text { Seasonal } \\
\text { Performance }\end{array}$} & \multicolumn{2}{|c|}{$\begin{array}{l}\text { Heat Pump Energy } \\
\text { Delivered (MBtu/yr) }\end{array}$} & \multicolumn{2}{|c|}{$\begin{array}{l}\text { Heat Pump Energy } \\
\text { Use }(\mathrm{kWh} / \mathrm{yr})\end{array}$} & \multirow{2}{*}{$\begin{array}{c}\text { Fan \& Pump } \\
\text { Energy Use } \\
(\mathrm{kWh} / \mathrm{yr})\end{array}$} & \multirow{2}{*}{$\begin{array}{c}\text { Total } \\
\text { Energy Use } \\
(\mathbf{k W h} / \mathbf{y r})\end{array}$} & \multirow{2}{*}{$\begin{array}{c}\text { Energy } \\
\text { Savings } \\
\text { (kWh/yr) }\end{array}$} \\
\hline & COP & EER & Heating & Cooling & Heating & Cooling & & & \\
\hline \multicolumn{10}{|c|}{ Sacramento } \\
\hline Air-to-air & 1.57 & 6.43 & 40.56 & 7.90 & 7,574 & 1,229 & 1,470 & 10,273 & \\
\hline Hydronic & 1.57 & 6.43 & 30.47 & 7.68 & 5,690 & 1,195 & 609 & 7,494 & 2,778 \\
\hline \multicolumn{10}{|l|}{ Houston } \\
\hline Air-to-air & 1.49 & 7.22 & 19.46 & 30.60 & 3,838 & 4,238 & 1,367 & 9,444 & \\
\hline Hydronic & 1.49 & 7.22 & 15.98 & 29.28 & 3,153 & 4,057 & 769 & 7,978 & 1,466 \\
\hline \multicolumn{10}{|l|}{ Phoenix } \\
\hline Air-to-air & 1.54 & 5.29 & 15.75 & 43.88 & 2,996 & 8,293 & 2,625 & 13,915 & \\
\hline Hydronic & 1.54 & 5.29 & 12.27 & 41.37 & 2,333 & 7,819 & 973 & 11,125 & 2,789 \\
\hline \multicolumn{10}{|l|}{ Denver } \\
\hline Air-to-air & 1.51 & 7.64 & 65.49 & 4.35 & 12,679 & 570 & 1,260 & 14,509 & \\
\hline Hydronic & 1.51 & 7.64 & 48.12 & 4.50 & 9,316 & 589 & 746 & 10,651 & 3,857 \\
\hline
\end{tabular}

This approach assumes that the effectiveness of the refrigerant-to-air indoor coil coupled with the standard heat pump is equivalent to the effectiveness of the refrigerant-to-water coil coupled to the multiple water-to-air coils. With the exception of data obtained during the summer of 2011 under a separate Building America project located in Tucson, there is no known laboratory or field test data to support this assumption. Monitoring data from the Tucson site show that the Aqua Products system using a 13 SEER heat pump yielded an average seasonal EER of 10.7, including pump and limited fan energy (German, 2011a). Thus, the assumed EERs for the hydronic heat pump used in the calculation of annual energy savings in Table 5 may be conservative.

Field data from the Tucson house and another house in Chico, California, that ARBI is currently monitoring will shed more light on the performance of air-to-water heat pumps. The data will contribute to development of realistic performance maps for the two systems that can be used for future evaluations. 


\section{Analysis of Zoning Impacts}

Adding zoning to hydronic systems does not introduce the same difficulties as zoning with forced air systems. Compared to air systems, hydronic systems are relatively immune to the problem of increased fluid velocity and pressure when fewer than all zones are operating. For example, the increased pressure in piping does not cause the noise or leakage problems experienced with duct systems. Pumps are available that throttle flow in response to increasing pressure, and heat exchanger penalties are reduced because of the higher heat capacity of water.

To explore the potential benefits of zoning from an energy use standpoint, additional TRNSYS modeling was completed to determine whether zoning would further improve distribution efficiency. The house model shown in Figure 9 was modified to include thermostats in each of three zones (Living, Master Bedroom, and Guest Bedrooms) to control zone valves. Identical temperature schedules were used in all zones. A variable speed pump was modeled such that the pump would maintain equal pressures to meet the flow requirements of each respective zone.

Results, shown for the Sacramento climate in Table 6, indicate that introducing zoning decreases fan and pump energy use but increases heat pump and total energy use. Similar results were seen for the other four climate zones. This outcome is surprising considering the favorable (Altherma) part load performance map incorporated in the model.

Table 6. Energy Use Comparison Between a Single Zone and Multizone Hydronic Distribution for the Sacramento Climate

\begin{tabular}{|l|r|r|r|r|r|}
\hline & $\begin{array}{c}\text { Annual Heat } \\
\text { Pump Heating } \\
\text { SyWhtem Type }\end{array}$ & $\begin{array}{c}\text { Annual Heat } \\
\text { Pump Cooling } \\
\mathbf{( k W h / y r )}\end{array}$ & $\begin{array}{c}\text { Annual } \\
\text { Pump } \\
\text { (kWh/yr) }\end{array}$ & $\begin{array}{c}\text { Annual } \\
\text { Fan } \\
\mathbf{( k W h / y r )}\end{array}$ & $\begin{array}{c}\text { Total } \\
\mathbf{( k W h / y r )}\end{array}$ \\
\hline Ductless-Single Zone & 3,241 & 522 & 158 & 451 & $\mathbf{4 , 3 7 3}$ \\
\hline Ductless-MultiZones & 3,554 & 538 & 126 & 347 & $\mathbf{4 , 5 6 6}$ \\
\hline Savings & -313 & -16 & 32 & 104 & $\mathbf{- 1 9 3}$ \\
\hline \% Savings & $-10 \%$ & $-3 \%$ & $20 \%$ & $23 \%$ & $\mathbf{- 4 \%}$ \\
\hline
\end{tabular}

Upon further investigation, it was noted that the entering water temperature during heating was on average $7^{\circ} \mathrm{F}$ warmer for the multizone case. This effect is expected because when fewer zones are calling for heat, a smaller load is imposed on the system and the circulation loop returns water at a higher temperature to the heat pump than if all zones were being called simultaneously. This results in greater thermal lift. It appears that the increased thermal lift combined with lower part load efficiency trumps increased heating load resulting from overheating of the bedroom zones. Also, the integrity of the thermal enclosure and mass of the slab may have diminished the value of distributing heat only to those zones that require it.

TRNSYS results do suggest that zoning can provide improved comfort. The temperature graphs below are for a typical heating day in Sacramento. The average outdoor temperature over the 24hour period was $40^{\circ} \mathrm{F}$ with a low of $34^{\circ} \mathrm{F}$. Figure 11 plots the indoor temperature profiles with the system modeled as a single zone. The bedrooms and master suite rise above the $72^{\circ} \mathrm{F}$ heating setpoint by $4^{\circ} \mathrm{F}$ during each heating call. Figure 12, which plots temperatures in a zonecontrolled system, shows much less dramatic temperature swings. During the same 24-hour period the bedroom only called four times for heating in the zoned case but six times with the 
single zone case. Further research is needed to determine whether the zoning penalty seen in the TRNSYS results is supported by field data. The improved temperature control in a zoned house, as well as the opportunity to modify thermostat settings in unoccupied zones, should yield energy savings.

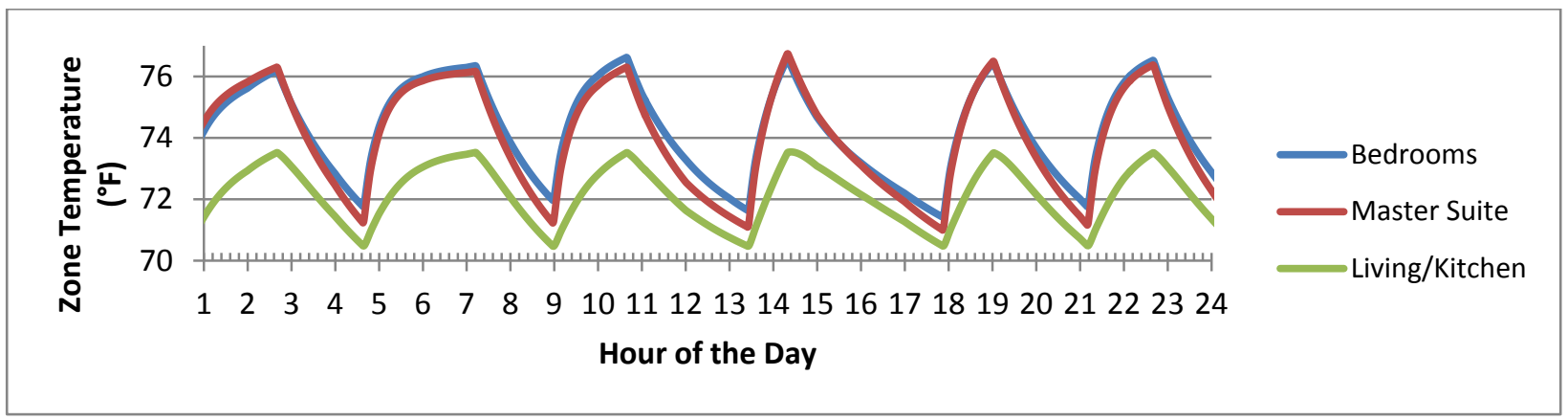

Figure 11. Indoor temperature profiles during heating for Sacramento house, unzoned case

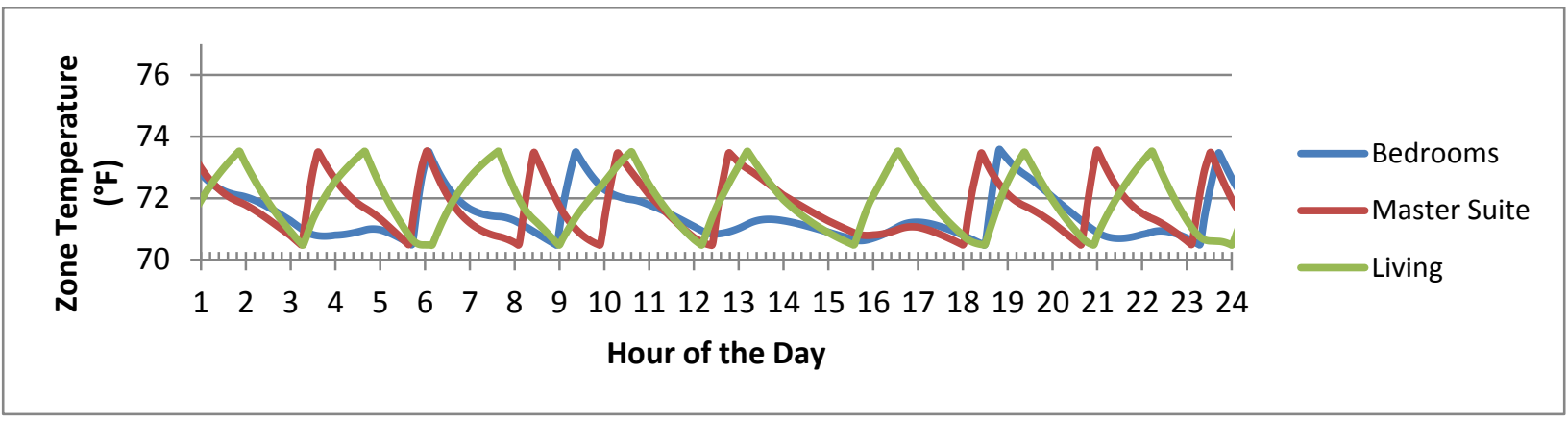

Figure 12. Indoor temperature profiles during heating for Sacramento house, multi zoned case

\subsection{Cost Estimates and Economic Evaluation}

To evaluate the economics of ductless hydronic vs. forced air distribution, costs were compiled for the primary components of each system type that was modeled (see the Appendix for details).

An incremental cost of $\$ 1200$ was estimated to account for the refrigerant-to-water heat exchanger and controls added to a conventional heat pump (comparable to Aqua Products). The incremental costs were amortized over 30 years using a $6 \%$ interest rate. The utility savings are based on the estimated energy use in Table 4 and assume a flat rate for electricity of $\$ 0.116$ per $\mathrm{kWh}$ (based on an approximate national average at the time of the study). Installation labor is included in duct and pipe costs but not in the cost of other components. 
Table 7. Cost Effectiveness Analysis ${ }^{8}$

\begin{tabular}{|c|rr|rr|r|rr|rr|}
\hline \multirow{2}{*}{ Climate Zone } & \multicolumn{2}{|c|}{ Estimated Installed } & \multicolumn{2}{c|}{$\begin{array}{c}\text { Capital } \\
\text { Cost } \\
\text { Savings }\end{array}$} & $\begin{array}{c}\text { Annual } \\
\text { Utility Cost } \\
\text { Savings }\end{array}$ & $\begin{array}{c}\text { Annual } \\
\text { Average } \\
\text { Cash }\end{array}$ \\
\hline Sacramento & $\$$ & 2,242 & $\$$ & 4,481 & $\$(2,238)$ & $\$$ & 322 & $\$$ & 161 \\
\hline Houston & $\$$ & 2,242 & $\$$ & 4,667 & $\$(2,424)$ & $\$$ & 170 & $\$$ & $(4)$ \\
\hline Phoenix & $\$$ & 2,242 & $\$$ & 4,667 & $\$(2,424)$ & $\$$ & 324 & $\$$ & 149 \\
\hline Denver & $\$$ & 2,242 & $\$$ & 4,587 & $\$(2,344)$ & $\$$ & 447 & $\$$ & 279 \\
\hline
\end{tabular}

The majority of the incremental cost $(53 \%)$ is attributed to the air terminal units which, for purposes of this cost analysis, were assumed to be small horizontal fan coils costing about $\$ 795$ each (based on a quote from MagicAire). The Airdale ceiling cassettes cost about $\$ 2000$ each. Given the components involved (small fan with efficient motor, small coil, condensate pan, housing, and diffuser), it is likely that the mature market cost for such a product would be considerably lower. Not counted in the savings is the elimination of the cost for HERS tests of duct tightness and verified refrigerant charge.

\section{Conclusions}

Hydronic distribution is a viable alternative to forced air distribution that increases construction costs but can have very favorable economic value, and eliminates the architectural challenges and cost of locating ducts in conditioned space. Separate challenges may exist in identifying space for distributed fan coils and running multiple condensate drains in units used for cooling. Properly designed hydronic systems can also serve very small heating loads.

The use of thermal storage such as through water storage tanks or radiant slab distribution allow the heat pump to operate under more favorable full load conditions producing additional energy savings. Preliminary results from research completed under another Building America technical report (German, 2011b) showed energy savings and efficiency improvements through precooling the building slab in the summer by running the heat pump between 1:00 a.m.-6:00 a.m. and letting the building coast during the day, shifting air conditioning operation to periods when it is cooler outside. Systems that incorporate thermal storage (water storage or radiant floors) provide added value in locations that have time-of-use rates.

TRNSYS simulations predicted 16\%-27\% energy savings in the four climate zones evaluated relative to traditional ducted systems, using conservative performance parameters for the air-towater heat pump. The highest savings are associated with heating dominated climates. The model also indicated an improvement in distribution efficiency averaging 16\%. TRNSYS predicted energy savings of 55\% when the hydronic system is coupled to an inverter driven Altherma heat pump, but the cost of this equipment is considerably higher (about $\$ 8,000$ -

\footnotetext{
${ }^{8}$ Installed costs are not total installed costs but only consider components that differ between the two system types.
} 
$\$ 9,000$ incremental). The Altherma can also provide efficient heat pump water heating, the cost advantage of which is not evaluated in this report.

Two field monitoring projects that incorporate radiant floor distribution are underway. Additional field studies are needed to evaluate forced air distribution with no or minimal ducting to validate the TRNSYS data. Field monitoring data is also needed to develop realistic performance maps for air-to-water heat pumps that are based on entering water temperature, outdoor temperature, and part load for radiant and forced air terminal distribution systems.

The predominant barriers to widespread commercialization are the cost and availability of air-towater heat pumps (as well as ground-coupled water-to-water heat pumps) and particularly small forced air terminal units. There are no technological barriers to the development of either, and increased market demand would prompt the introduction of new and lower cost products. Stakeholders such as manufacturers of heat pumps, fan coils, hydronic components, PEX tubing, and the home building industry should be informed of this opportunity. A minor barrier is the differentiation of services between plumbing and mechanical contractors, who would be required to work together in ways that may be unfamiliar in certain regions of the United States. 


\section{Appendix}

\section{Load Calculations and Equipment Performance Assumptions}

Loads and airflow requirements were completed for each of the four climates using the Manual J and D components of Right-Suite Universal. The base case assumes ducts in a vented attic with moderate leakage $(\approx 20 \%)$. Table A-1 lists results of these calculations and other assumptions used in the base case.

Table A-1. Base Case Load Calculations, Airflow, and Fan Power Assumptions

\begin{tabular}{|l|r|r|r|r|}
\hline Base Case with ducts in attic & Sacramento & Houston & Phoenix & \multicolumn{1}{l|}{ Denver } \\
\hline Heating Load (Btuh) & 39,917 & 42,767 & 37,922 & 47,112 \\
\hline Sensible Cooling Load (Btuh) & 32,887 & 33,612 & 51,178 & 22,891 \\
\hline Latent Cooling Load (Btuh) & 920 & 6,793 & 0 & 0 \\
\hline Total Airflow (cfm) & 1,596 & 1,597 & 2,622 & 1,025 \\
\hline Fan Power(W) & 581 & 581 & 954 & 373 \\
\hline Living Flow (CFM) & 263 & 263 & 435 & 188 \\
\hline Living Duct Diameter (in) & 10 & 10 & 14 & 10 \\
\hline Kitchen (cfm) & 403 & 403 & 660 & 248 \\
\hline Kitchen Duct Diameter (in) & 10 & 10 & 14 & 9 \\
\hline Bedrooms (cfm) & 489 & 489 & 803 & 308 \\
\hline Bedroom Duct Diameter (in) & 10 & 10 & 12 & 10 \\
\hline Master Bed (cfm) & 441 & 442 & 724 & 281 \\
\hline Master Duct Diameter (in) & 12 & 12 & 16 & 10 \\
\hline
\end{tabular}

To develop the air-to-air heat pump model, the equipment capacity, heating and cooling EIR, and DOE-2 performance coefficients were entered into TRNSYS. The DOE-2 coefficients for a SEER 13, 7.7 HSPF heat pump were taken from BEopt option editor. Equipment performance parameters used are listed in Table A-2.

Table A-2: Base Case Heat Pump Performance Parameters

\begin{tabular}{|l|c|}
\hline Equipment Type & HP \\
\hline Nominal SEER Value & 13 \\
\hline EER & 11.07 \\
\hline Nominal Sens. Heat Ratio & 0.726 \\
\hline Nominal Cooling EIR & 0.2718 \\
\hline Nominal HSPF & 7.7 \\
\hline Nominal COP & 3.28 \\
\hline Nominal Heating EIR & 0.3202 \\
\hline
\end{tabular}

For the ductless hydronic case, the building loads were recalculated assuming no duct losses (piping losses are accounted for in the TRNSYS model). The modified loads were used to size the terminal units for each zone. 


\section{Ductless Hydronic System Assumptions}

The ductless hydronic system modeled had three zones with MagicAire type units serving the Kitchen/Living, Master Suite, and Bedrooms. Even though each zone had an exclusive fan delivery system, the operation was controlled by a single thermostat, located in the living room. The fan power was assumed constant during operation. Table A-3 lists system loads and specifications.

Table A-3. Ductless Hydronic System Loads and Specifications

\begin{tabular}{|c|c|c|c|c|}
\hline & Sacramento & Houston & Phoenix & Denver \\
\hline Heating Load (Btuh) & 32,000 & 33,404 & 25,343 & 38,895 \\
\hline HP rated heating Power $(\mathrm{W})$ & 2,859 & 2,985 & 2,265 & 3,475 \\
\hline Sensible Cooling Load (Btuh) & 21,724 & 22,099 & 29,359 & 16,434 \\
\hline Latent Cooling Load (Btuh) & 706 & 4190 & 0 & 0 \\
\hline HP rated Cooling Power $(\mathrm{W})$ & 2,040 & 2,390 & 2,670 & 1,494 \\
\hline Total Hydronic Pump Flow (gpm) & 5.32 & 6.54 & 6.58 & 5.94 \\
\hline \multicolumn{5}{|l|}{3 Zone Scenario } \\
\hline \multicolumn{5}{|l|}{ Living/Kitchen } \\
\hline MagicAire System & CHA04 & CHA06 & CHA06 & CHA06 \\
\hline Airflow & 400 & 500 & 500 & 400 \\
\hline$\%$ air delivered to Kitchen vs. Living & $61 \%$ & $61 \%$ & $61 \%$ & $61 \%$ \\
\hline Fan Power $(\mathrm{W})(0.365$ Watts/cfm $)$ & 146 & 182.5 & 182.5 & 146 \\
\hline Hydronic Flow & 2.08 & 2.6 & 2.73 & 2.6 \\
\hline$\%$ of Total Hydronic Flow & $39 \%$ & $40 \%$ & $41 \%$ & $44 \%$ \\
\hline Pipe Diameter & $3 / 4$ & $3 / 4$ & $3 / 4$ & $3 / 4$ \\
\hline \multicolumn{5}{|l|}{ Bedrooms } \\
\hline MagicAire System & CHA02 & CHA04 & CHA04 & CHA04 \\
\hline Airflow & 265 & 400 & 400 & 300 \\
\hline Fan Power (W) (0.365 Watts/cfm) & 97 & 146 & 146 & 110 \\
\hline Hydronic Flow & 1.9 & 2.04 & 1.95 & 1.9 \\
\hline$\%$ of Total Hydronic Flow & $36 \%$ & $31 \%$ & $30 \%$ & $32 \%$ \\
\hline Pipe Diameter & $3 / 4$ & $3 / 4$ & $3 / 4$ & $3 / 4$ \\
\hline \multicolumn{5}{|l|}{ Master Suite } \\
\hline MagicAire System & CHA02 & CHA04 & CHA04 & CHA02 \\
\hline Airflow & 200 & 300 & 300 & 265 \\
\hline Fan Power $(\mathrm{W})(0.365$ Watts/cfm $)$ & 73 & 109.5 & 109.5 & 96.725 \\
\hline Hydronic Flow & 1.34 & 1.9 & 1.9 & 1.44 \\
\hline$\%$ of Total Hydronic Flow & $25 \%$ & $29 \%$ & $29 \%$ & $24 \%$ \\
\hline Pipe Diameter & $1 / 2$ & $3 / 4$ & $3 / 4$ & $1 / 2$ \\
\hline
\end{tabular}




\section{Hydronic System Water Flow, Pipe, and Pump Sizing}

Design flow rates were based on a $15^{\circ} \mathrm{F}$ delta-T for heating and a $10^{\circ} \mathrm{F}$ delta-T for cooling. The hydronic piping was assumed to be cross-linked polyethylene (PEX). The Hazen-Williams method was used to calculate friction loss, and pipes were sized to limit total friction head loss to 4.5 feet of water per 100' of pipe at design flow rates. Pipe lengths were approximated from the plan and based on the storage tank located inside the garage and the heat pump being located outside the garage near the storage tank (see Figure 9). The pump was assumed to draw 45 Watts rated at a rated flow of $6.5 \mathrm{gpm}$. The equation below describes how fractional power $\left(\frac{\mathrm{P}}{\mathrm{P}_{\text {Rated }}}\right)$ varies as a function of fractional mass flow $\left(\frac{\mathrm{m}}{\mathrm{m}_{\text {Rated }}}\right)$ according to a $2^{\text {nd }}$ order polynomial. The coefficients were derived using performance data from a Grundfos Alpha pump.

$$
\frac{\mathrm{P}}{\mathrm{P}_{\text {Rated }}}=\left[-0.0099+{ }^{-} 0.0317\left(\frac{\mathrm{m}}{\mathrm{m}_{\text {Rated }}}\right)+1.0672_{2}\left(\frac{\mathrm{m}}{\mathrm{m}_{\text {Rated }}}\right)^{2} .\right]
$$

\section{Air-to-Water Heat Pump Performance Maps}

Data provided by Daikin for the Altherma heat pump were used to develop the performance maps shown in Figures A-1 through A-4.

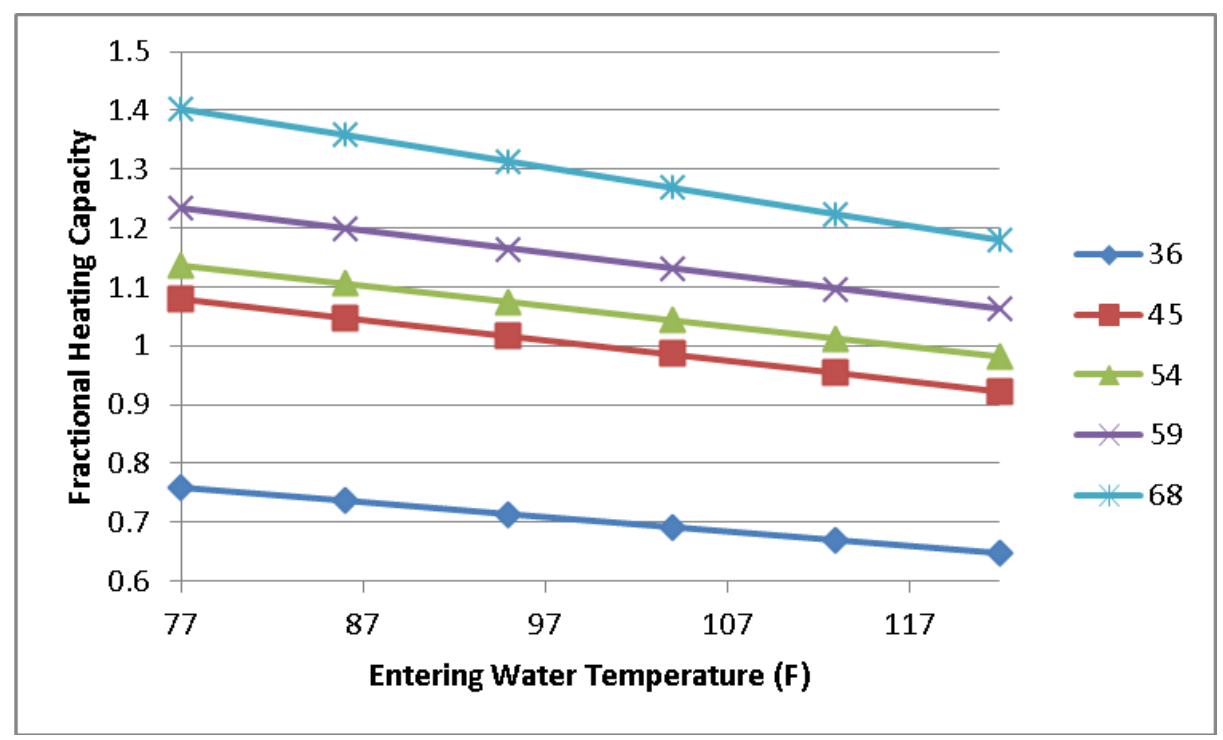

Figure A-1. Fractional heating capacity of Daikin Altherma as a function of entering water temperature for various outdoor temperature conditions 


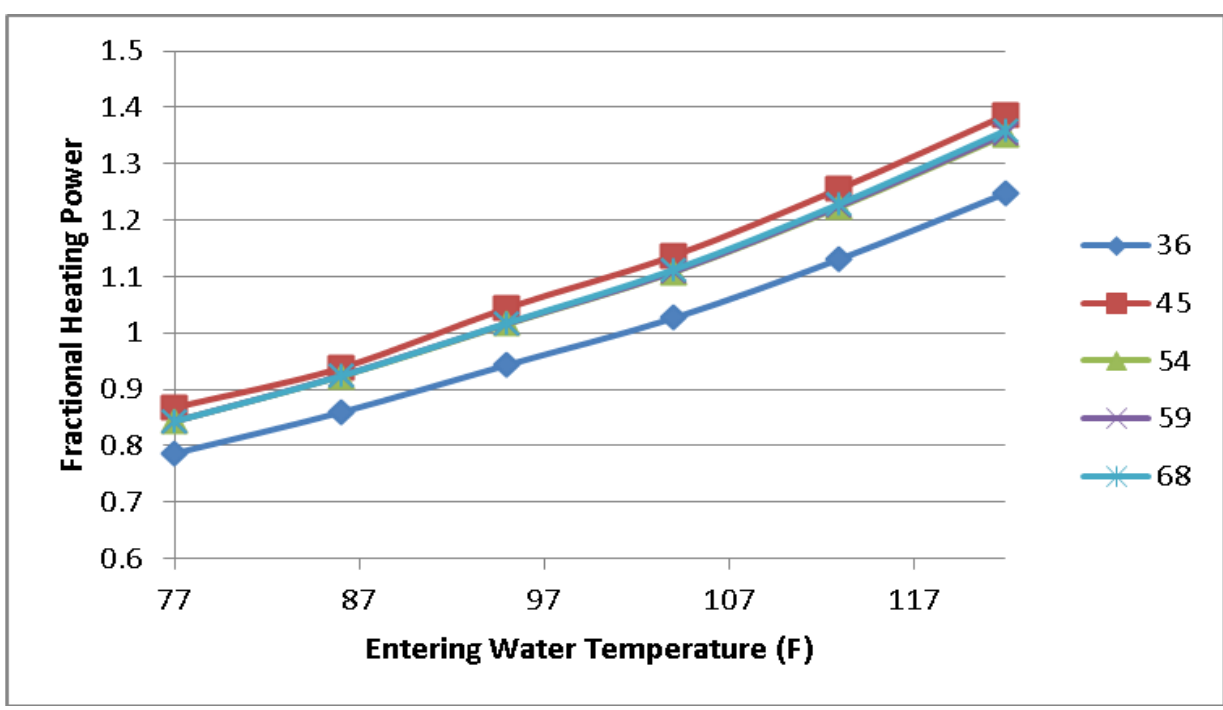

Figure A-2. Fractional heating power of Daikin Altherma as a function of entering water temperature for various outdoor temperature conditions

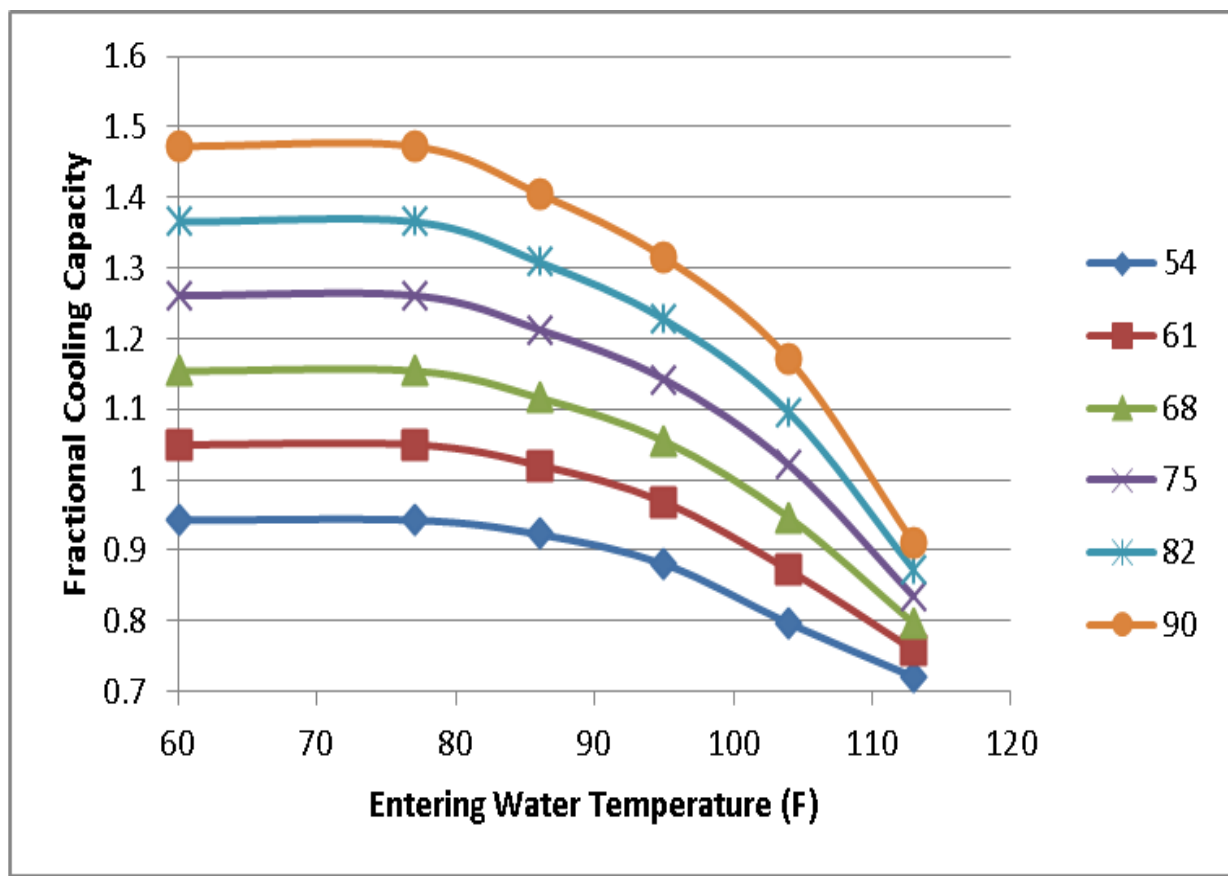

Figure A-3. Fractional cooling capacity of Daikin Altherma as a function of entering water temperature for various outdoor temperature conditions 


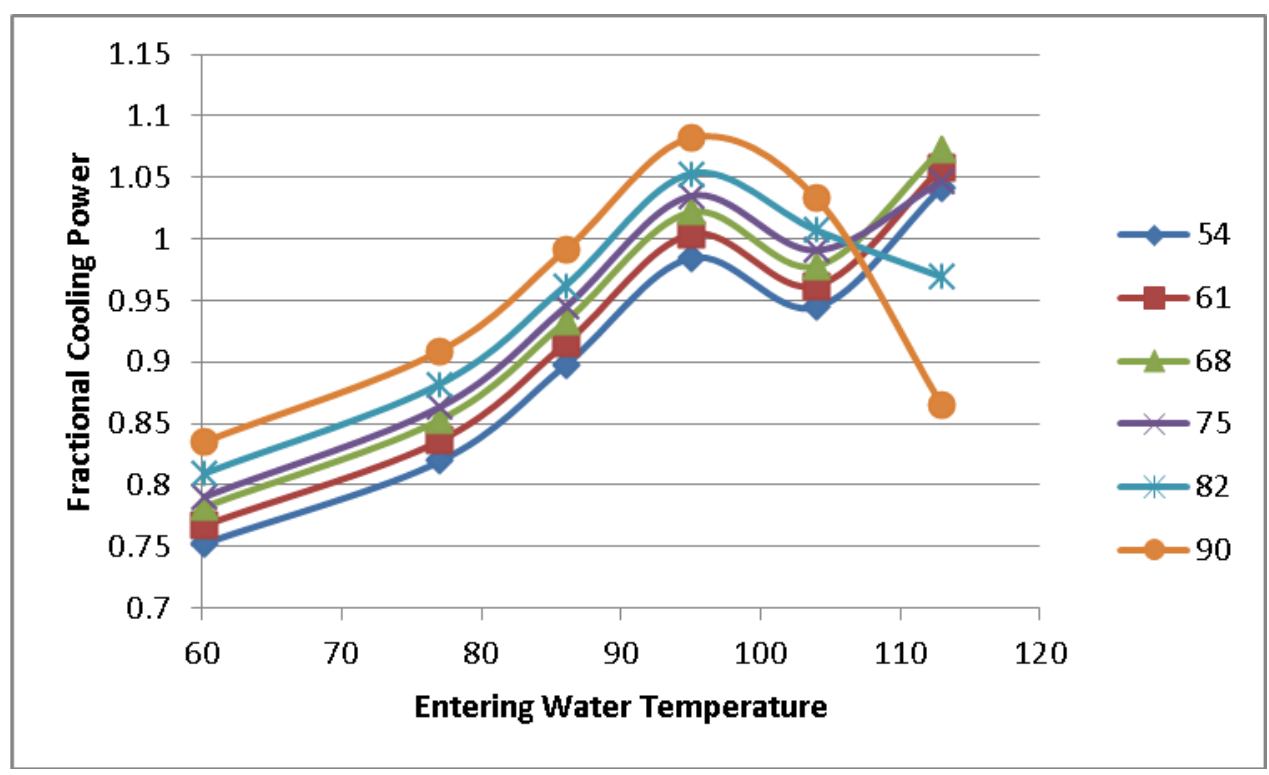

Figure A-4. Fractional cooling power of Daikin Altherma as a function of entering water temperature for various outdoor temperature conditions

\section{System Costs}

Detailed system costing is described in Table A-4 and Table A-5.

Table A-4. Base Case System Costs (all climates)

\begin{tabular}{|l|r|}
\hline HP Air Handler \& coil & $\$ 872$ \\
\hline Diffusers & $\$ 49$ \\
\hline Return Grilles & $\$ 19$ \\
\hline Ducts & $\$ 1,302$ \\
\hline TOTAL & $\$ 2,242$ \\
\hline
\end{tabular}

Table A-5: Hydronic System Costs

\begin{tabular}{|c|c|c|c|c|c|c|c|c|}
\hline \multirow[b]{2}{*}{ Water-Air HP (incremental) } & \multicolumn{2}{|c|}{ Sacramento } & \multicolumn{2}{|c|}{ Houston } & \multicolumn{2}{|c|}{ Phoenix } & \multicolumn{2}{|c|}{ Denver } \\
\hline & $\$$ & 1,200 & $\$$ & 1,200 & $\$$ & 1,200 & $\$$ & 1,200 \\
\hline Living Zone Fan Coil & $\$$ & 795 & $\$$ & 848 & $\$$ & 848 & $\$$ & 848 \\
\hline Bedrooms Fan Coil & $\$$ & 742 & $\$$ & 795 & $\$$ & 795 & $\$$ & 795 \\
\hline Master Suite Fan Coil & $\$$ & 742 & $\$$ & 795 & $\$$ & 795 & $\$$ & 742 \\
\hline Piping & $\$$ & 276 & $\$$ & 303 & $\$$ & 303 & $\$$ & 276 \\
\hline Condensate Drain (incremental) & $\$$ & 94 & $\$$ & 94 & $\$$ & 94 & $\$$ & 94 \\
\hline Manifolds & $\$$ & 53 & $\$$ & 53 & $\$$ & 53 & $\$$ & 53 \\
\hline Diffusers & $\$$ & 23 & $\$$ & 23 & $\$$ & 23 & $\$$ & 23 \\
\hline Return Grille & $\$$ & 5 & $\$$ & 5 & $\$$ & 5 & $\$$ & 5 \\
\hline Pumps, heat pump \& zone & $\$$ & 371 & $\$$ & 371 & $\$$ & 371 & $\$$ & 371 \\
\hline Air separator & $\$$ & 103 & $\$$ & 103 & $\$$ & 103 & $\$$ & 103 \\
\hline Expansion tank & $\$$ & 29 & $\$$ & 29 & $\$$ & 29 & $\$$ & 29 \\
\hline Switching relay & $\$$ & 48 & $\$$ & 48 & $\$$ & 48 & $\$$ & 48 \\
\hline Total & $\$$ & 4,481 & $\$$ & 4,667 & $\$$ & 4,667 & $\$$ & 4,587 \\
\hline
\end{tabular}




\section{References}

ACCA Manual S. (1995). Manual S: Residential Equipment Selection. Air Conditioning Contractors of America. Arlington, VA.

ASHRAE Standard 152. (2004). Method of Test for Determining the Design and Seasonal Efficiencies of Residential Thermal Distribution Systems. American Society of Heating, Refrigeration, and Air Conditioning Engineers. Atlanta, GA.

ASHRAE Handbook - Systems and Equipment. (2008). Chapter 6 (Panel Heating and Cooling), Chapter 12 (Hydronic Heating and Cooling), and Chapter 35 (Hydronic Distribution and Radiators). American Society of Heating, Refrigeration, and Air Conditioning Engineers. Atlanta, GA.

Bean, R., Olesen, B.W., Kim, K.W. (2010). "History of Radiant Heating \& Cooling Systems Part 2.” ASHRAE Journal. February 2010.

DOE. (2010). "Building America House Simulation Protocols” DOE/GO-102010-3141: Building Technologies Program. U.S. Department of Energy

CEC (2012). "Final Evaluation Report - Proposed Compliance Option for Altherma Air-to-Water Source Heat Pump for the Residential Efficiency Standards." March 2012. California Energy Commission report number CEC-400-2011-010-SF.

German, A. et al. (2011a). “Technical Report: S.E.E.D. Home.” Building America draft project report completed under the Alliance for Residential Building Innovation (ARBI). To be available electronically at http://www.osti.gov/bridge. 2012.

German, A. et al. (2011b). "Technical Report: Air-to-Water Heat Pumps with Mixed Mode Delivery." Building America draft project report completed under the Alliance for Residential Building Innovation (ARBI). To be available electronically at http://www.osti.gov/bridge. 2012.

Hourahan, G.C., (2003). "Sizing and Selecting Equipment for Proper Humidity Control.” ARI Magazine. Spring 2003. pp 24-34.

Olesen, B.W. (2008). "Radiant Floor Cooling Systems.” ASHRAE Journal, September 2008. pp $16-22$.

Siegal, J.A., McWilliams, J., Walker, I.S. (2002). "Comparison Between Predicted Duct Effectiveness from Proposed ASHRAE Standard 152P and Measured Field Data for Residential Forced Air Cooling Systems." LBNL-50008. Lawrence Berkeley National Laboratory. Be

Siegenthaller, J. (2011). Modern Hydronic Heating, $3^{\text {rd }}$ Edition. Delmar Publishers, Albany NY.

Siegenthaller, J. (2010) “State of the Art Hydronics: Where Are We Headed?” ACI Energy Star Summit, Denver, CO. 
Smith, V; Baskin, E. (2003). Residential Hydronic Radiant Cooling and Heating Assessment. California Energy Commission. P-500-03-096-A14.

Springer, D., et al. (2007). Comparative Performance of Four Prototype Mechanical Systems in a Desert Climate. ASHRAE Transactions Vol. 114, Part 2.

Vineyard, E.A., Linkous, R.L. (2000). "Field Evaluation of a Residential Hydronic Distribution System in the Cooling Mode.” ASHRAE Transactions vol. 106, pt. 2. 


\section{U.S. DEPARTMENT OF Energy Efficiency \& ENERY Renewable Energy}

